\title{
PENINGKATAN NILAI TAMBAH PRODUK BARU DAN BARANG BEKAS
}

\author{
Ariefah Yulandari ${ }^{(1)}$ \\ Yolanyolan79.feusb@gmail.com \\ Widi Hariyanti ${ }^{(2)}$ \\ widihariyanti3011@gmail.com \\ Yunus Harjito ${ }^{(3)}$ \\ Fakultas Ekonomi Universitas Setia Budi
}

\begin{abstract}
Meningkatkan suatu nilai jual memiliki proses yang panjang. Berbagai metode dapat digunakan. Pemilihan metode yang tepatlah yang dapat membuat sebuah produk baru dan barang bekas menjadi lebih bernilai bahkan memiliki harga jual yang tinggi. Ini adalah proses yang dapat meningkatkan nilai kegiatan pelatihan kewirausahaan menuju ke tingkat perkembangan inovasi yang tinggi.

Berdasarkan analisis situasi, permasalahan yang dihadapi mitra adalah keinginan yang kuat dari mitra dalam pelatihan untuk berwirausaha akan tetapi rendahnya dalam pengetahuan untuk memberikan nilai tambah pada produk baru dan barang bekas rumah tangga yang dapat dijual dengan harga yang bersaing. Pengabdian masyarakat telah dilakukan dengan khalayak sasaran warga Gambirsari RW 03, Kelurahan Kadipiro, Kecamatan Banjarsari, Surakarta, dengan memberikan pengetahuan berupa pelatihan dalam bentuk meningkatkan produk barang baru dan barang bekas agar memiliki nilai jual yang cukup tinggi dengan metode decoupage ini membuahkan hasil yang membuat mitra ingin lebih mengembangkan pelatihan tersebut menjadi suatu usaha dalam menambah pendapatan keluarga dan menyelesaikan masalah sampah anorganik keluarga.
\end{abstract}

Kata kunci : Nilai tambah, decoupage, kerajinan, kewirausahaan.

\section{PENDAHULUAN}

Keluarga adalah wadah yang sangat penting diantara individu dan grup, dan merupakan kelompok sosial yang pertama dimana anak-anak menjadi anggotanya. Kondisi ekonomi keluarga yang dimaksud disini adalah kondisi ekonomi keluarga yang ditinjau dari status atau kedudukan perekonomian keluarga baik dari segi penghasilan mata pencaharian seseorang dalam memenuhi kebutuhan keluarga dari individu yang bersangkutan. Kondisi 
ekonomi ini dapat diukur dengan mengetahui pekerjaan/profesi, bentuk rumah, wilayah tempat tinggal ataupun lingkungan, dan sumber pendapatan.

Berdasarkan tuntutan itulah yang akan menjadikan dasar motivasi bagi keluarga dalam meningkatkan kesejahteraan keluarga melalui kewirausahaan. Dalam posisi ini siapa pun keluarga utama, ayah atau ibu yang akan melakukan tindakan menambah pendapatan keluarga dengan berwirausaha demi tujuan membuat kesejahteraan bagi keluarga terutama pada anak.

Terjadi krisis ekonomi pada tahun 1998 membawa dampak krisis ekonomi yang melanda Indonesia. Sejak tahun 1998 itulah membuat sendi-sendi kehidupan bangsa melemah dan diperparah dengan situasi politik tidak kondusif. Dampak yang begitu parah tersebut membuat perekonomian terkecil suatu bangsa yaitu keluarga terimbas dampaknya. Hal tersebut membuat angka kemiskinan negara semakin membengkak secara signifikan diikuti dengan memburuknya kesempatan kerja, banyaknya kepala keluarga yang mengalami pemutusan hubungan kerja sehingga mempertinggi angka pengangguran dan tindakan kriminal.

Besarnya dampak krisis ekonomi membuat keluarga harus berpikir keras membangun ekonomi keluarga. Penyelesaian dari masalah kritisnya perekonomian keluarga adalah melakukan kegiatan kewirausahaan atau berwirausaha. Berwirausaha merupakan salah satu dari sekian penyelesaian masalah suatu negara terutama negara yang sedang berkembang. Berdasarkan latar belakang tersebut, kehadiran dan peranan wirausaha tentunya akan memberikan pengaruh terhadap kemajuan perekonomian dan perbaikan pada keadaan ekonomi keluarga dan negara sekarang ini. Menjadi wirausaha berarti memiliki kemampuan menemukan dan mengevaluasi peluang-peluang mengumpulkan sumber - sumber daya yang diperlukan dan bertindak untuk memperoleh keuntungan dari peluang - peluang tersebut dan berinovasi secara kreatif membangun ekonomi kreatif seiring meningkatnya kewirausahaan masyarakat di 15 sektor di Indonesia. Hal tersebut diharapkan perekonomian di Indonesia juga meningkat.

Modal akan menjadi masalah utama para pelaku wirausaha. Maka dari itu harus ada motivasi dan keyakinan yang kuat bahwa permasalahan modal bukan menjadi halangan bagi berwirausaha. Kepentingan yang lebih penting dari hanya sekedar modal adalah ilmu 
pengetahuan dalam berinovasi dan ketekunan serta kreatifitas dalam mempergunakan kesempatan dalam melihat peluang usaha.

Lingkungan masyarakat di Gambirsari Kelurahan Kadipiro, Kecamatan Banjasari, Kota Surakarta memiliki memiliki tekat untuk berwirausaha menambah pendapatan keluarga. Permasalahan sebagian warga penduduk di Gambirsari Kelurahan Kadipiro, Kecamatan Banjasari, Kota Surakarta khususnya para ibu rumah tangga adalah masalah penumpukan limbah rumah tangga. Selain limbah tersebut juga menjadi masalah bagi pemerintah, para warga ingin limbah rumah tangga tersebut menjadi bermanfaat dalam meningkatkan perekonomian keluarga. Sampah yang biasanya disebut sampah anorganik adalah sampah yang dihasilkan dari bahan-bahan non-hayati, yang biasanya berupa produk sinterik maupun hasil proses teknologi pengolahan bahan tambang. Sampah anorganik ialah sampah yang dihasilkan dari bahan-bahan non hayati baik berupa produk sinterik maupun hasil prosses teknologi pengelolahan bahan tambang atau sumber daya alam dan tidak dapat diuraikan oleh alam, Contohnya: botol plastik, tas plastik, kaleng.

Sangat dibutuhkan suatu dorongan agar para ibu rumah tangga ini dapat menciptakan suatu kewirausahaan ekonomi kreatif melalui produk baru terutama barang bekas yang dapat dijual dengan harga bersaing dan dapat menambah pendapatan keluarga sesuai harapan. Dipilihnya wirausaha yang bergerak dibidang ekonomi kreatif tentang membuat barang yang tidak layak bahkan tidak layak untuk dijual dapat dijual bahkan dengan harga yang tinggi melalui kreatifitas dan metode yang tepat.

Bidang pengembangan ekonomi kreatif merupakan pilihan strategi yang tepat dan menjadi salah satu solusi yang dipandang dapat meningkatkan nilai guna suatu barang menjadi berharga dari hanya sekedar sampah yang dapat menjanjikan menjadi pendapatan. Selain itu ekonomi kreatif tidak hanya ditentukan dari seberapa baik dan besar suatu proses produksi yang dilakukan tetapi harus membawa aspek kreativitas dan inovasi yang memegang peranan penting selain seiring waktu berjalan fakktor teknologi juga akan memberikan pengaruh kuat terhadap laju perkembangan ekonomi kreatif itu sendiri dan nilai essensial terhadap barang yang dianggap sampah pada awal mulanya.

Membantu pemerintah dalam misinya untuk mendorong masyarakat menjadi wirausahawan baru yang sukses sehingga menciptakan banyak lapangan kerja baru yang 
menyerap banyaknya jumlah penggangguran yang ada Indonesia, membuat konsep ekonomi kreatif merupakan strategi yang dianggap tepat untuk membentuk pola pemikiran yang rutin ditanamkan kepada masyarakat serta memberi motivasi untuk berwirausaha karena itu merupakan sebagai modal utama untuk berwirausaha dengan konsep ekonomi kreatif guna meningkat kesejahteraan masyarakat Indonesia yang relatif masih rendah yang diharapkan mampu memberikan memotivasi masyarakat untuk berwirausaha meski dengan modal yang sangat terbatas. Membudayakan berwirausaha disertai pemanfaatan konsep ekonomi kreatif dinilai cukup efektif karena ada cukup banyak wirausahawan baru yang muncul dan menuai sukses dengan berbekal dua hal penting tersebut.

Hal diatas disampaikan oleh Aisyah Nurul Fitriana, Irwan Noor, dan Ainul Hayat (2014) bahwa perkembangan industri kreatif sangat membutuhkan sumber daya manusia yang inovatif dan kreativitas yang tinggi.

\section{TINJAUAN PUSTAKA}

Definisi yang lebih jelas disampaikan oleh UNDP/UNCTAD (2008) yang merumuskan bahwa ekonomi kreatif merupakan bagian integratif dari pengetahuan yang bersifat inovatif, pemanfaatan teknologi secara kreatif, dan budaya. Departemen Perdagangan (2007) menyusun sebuah rancangan pengembangan dalam menghadapi persaingan dalam bidang ekonomi kreatif yang terbagi menjadi 14 sektor yaitu periklanan, arsitektur, pasar barang seni, kerajinan, desain, fashion, film-video dan fotografi, permainan interaktif, musik, seni pertunjukan, penerbitan dan percetakan, layanan komputer, radio dan televisi (Simatupang, 2008). Dalam perkembangannya, ada penambahan beberapa sektor industri sebagai inkubator industri kreatif, yaitu agrobisnis, kuliner, dan otomotif (Murniati, 2009). Dalam pelaksanaannya industri kecil dan menengah banyak mendominasi dan menggerakkan industri kreatif (Murniati, 2009).

Ekonomi kreatif merupakan suatu konsep di era sekarang ini dalam bidang ekonomi yang mengintensifkan informasi dan kreativitas yang selalu mengandalkan ide-ide dan pengetahuan yang dimiliki oleh sumber daya manusia agar berproduksi. Sistem ekonomi kreatif ini sebagai cara pengembangan dibidang ekonomi dengan menumbuhkan ide 
kreativitas yang dimiliki masyarakat untuk berproduksi dalam upaya menaikkan tingkat pendapatan. Sistem ekonomi kreatif di Indonesia mulai berkembang sejak tahun 2006, dengan diwujudkannya pembentukan Indonesia Design Power oleh Departemen Perdagangan. Perkembangan ekonomi kreatif di Indonesia tersebut didukung oleh pemerintah dengan adanya peluncuran Cetak Biru Pengembangan 14 Subsektor Industri Kreatif Indonesia pada tahun 2008.

Berdasarkan perkembangan konsep dan definisi mengenai ekonomi kreatif, maka ekonomi kreatif dapat didefinisikan sebagai penciptaan nilai tambah berbasis ide yang lahir dari kreativitas sumber daya manusia (orang kreatif) dan berbasis pemanfaatan ilmu pengetahuan, termasuk warisan budaya dan teknologi. Sumber daya utama dalam ekonomi kreatif adalah kreativitas (creativity) yang didefinisikan sebagai kapasitas atau kemampuan untuk menghasilkan atau menciptakan sesuatu yang unik, menciptakan solusi dari suatu masalah atau melakukan sesuatu yang berbeda dari pakem (thinking outside the box). Kreativitas merupakan faktor yang menggerakkan lahirnya inovasi (innovation) dengan memanfaatkan penemuan (invention) yang sudah ada. Inovasi merupakan transformasi atau implementasi dari ide atau gagasan berdasarkan kreativitas dengan memanfaatkan penemuan-penemuan yang ada untuk menghasilkan produk atau proses yang lebih baik, bernilai tambah, dan bermanfaat. Sedangkan penemuan adalah menciptakan sesuatu yang belum pernah ada sebelumnya dan diakui sebagai karya yang memiliki fungsi unik. Oleh karena itu, kreativitas sangat penting dalam mendorong lahirnya inovasi-inovasi yang berdaya guna dan berdaya saing.

Menurut Bebassari (2008), secara umum terdapat lima aspek penting dalam pengelolaan sampah yaitu teknologi, institusi, hukum/peraturan, pembiayaan dan partisipasi masyarakat. Sampah-sampah yang didaur ulang oleh masyarakat dapat menjadi berbagai kerajinan bisa dijual dan tentunya akan memberikan penghasilan tambahan bagi masyarakat. Walaupun jumlah keuntungan dari penjualan barang daur ulang tersebut tidak signifikan, setidaknya itu dapat terus memotivasi masyarakat untuk berkreasi dan sekaligus peduli dengan lingkungannya. Salah satu pemanfaatan limbah anorganik adalah dengan cara proses daur ulang (recycle). Daur ulang merupakan upaya untuk mengolah barang atau benda yang sudah tidak dipakai agar dapat dipakai kembali. Beberapa limbah anorganik yang dapat 
dimanfaatkan melalui proses daur ulang, misalnya plastik, gelas, logam, dan kertas (Syahriartato 2014).

Sampah rumah tangga jenis anorganik adalah salah satu bahan yang bisa di pakai atau digunakan kembali jika diberi nilai tambah yang membuat barang bekas yang menjadi limbah rumah tangga tersebut menjadi memiliki nilai jual yang tinggi dengan harapan dapat dipasarkan dan menjadi salah satu terbukanya kegiatan kewirausahaan. Nilai (value) itu sendiri dalam bisnis adalah perbedaan antara harga jual dan biaya produksi suatu produk adalah laba unit. Dalam ekonomi, jumlah laba unit, biaya penyusutan unit, dan biaya tenaga kerja unit adalah nilai tambah unit. Menjumlahkan nilai tambah per unit atas semua unit yang terjual adalah nilai tambah total (Wikipedia).

\section{METODE PELAKSANAAN}

Melatih dan membiasakan diri untuk lebih berkreatif dengan berbagai metode salah satunya dengan metode decoupage sebagai metode pengembangan produk dalam memberikan nilai tambah produk bertujuan menaikkan volume penjualan.

Decoupage adalah yang berasal dari bahasa Prancis découper atau berarti memotong, merupakan kerajinan atau bentuk seni yang memerlukan potongan-potongan bahan (biasanya kertas) yang ditempel pada objek dan kemudian dilapisi dengan pernis atau pelitur. Proses ini membuat tampilan potongan-potongan kertas yang rata tampak dalam dan membuat pola serta gambar terlihat seolah-olah dilukis pada objek yang diproses dengan teknik decoupage. Decoupage adalah cara menyenangkan dan mudah untuk mendekorasi objek apa saja, termasuk benda-benda di rumah mulai dari vas kecil hingga furnitur berukuran besar. Kemungkinannya sangatlah banyak. Namun, untungnya, decoupage bisa dipelajari relatif cepat hanya dengan beberapa langkah.

Cara mengolah produk limbah rumah tangga atau barang bekas dan barang baru sebagai berikut :

1) Siapkan media yang akan ditempel napkin. Bersihkan menggunakan amplas jika dibutuhkan untuk menghaluskan agar napkin menempel dengan sempurna. Jika memang ada kombinasi harus di cat, cat media tersebut dengan warna yang sesuai. 
2) Gunting atau sobek napkin atau kertas tissue sesuai dengan gambar yang dinginkan. Sebisa mungkin cari motif napkin yang sesuai selera konsumen atau yang sedang ngetren. Sesuaikan gambar napkin dengan warna dasar catnya.

3) Campur lem dengan air dengan perbandingan $2: 1$. Atur letak napkin pada media, lalu tempelkan napkin dengan menggunakan lem.

4) Berikan lem atau kuas kembali napkin dengan lem yang sama dan tunggu sampai kering.

5) Setelah permukaan kering, kuaskan varnish diatas napkin dan tunggu hingga kering.

Pelatihan yang diberikan memiliki tujuan menumbuhkan minat berwirausaha yang baik, pemanfaatan sampah rumah tangga, melatih kreatifitas serta inovasi dan meningkatkan nilai tambah produk sehingga peserta pelatihan dapat meningkatkan kehidupan perkeonomian keluarga menjadi lebih baik.

Ada pun untuk mencapai tujuan itu dilakukan alur sebagai berikut :

\begin{tabular}{|c|c|c|}
\hline Awal & Pelatihan & Outcome \\
\hline $\begin{array}{lr}\text { Masyarakat } & \text { belum } \\
\text { memiliki } & \text { minat } \\
\text { berwirausaha } & \text { dan } \\
\text { Masyarakat yang } & \text { sudah } \\
\text { berwirausaha } & \text { tapi } \\
\text { keduanya belum memiliki } \\
\text { ketrampilan } \\
\text { meningkatkan } \\
\text { produk menjadi bernilai } \\
\text { tinggi. }\end{array}$ & $\begin{array}{l}\text { b. Pelatihan ketrampilan } \\
\text { memberikan nilai } \\
\text { tambah produk pada } \\
\text { barang baru dan barang } \\
\text { bekas dengan } \\
\text { menggunakan metode } \\
\text { decoupage. }\end{array}$ & $\begin{array}{l}\text { a. Tumbuhnya minat } \\
\text { para peserta untuk } \\
\text { memulai } \\
\text { berwirausaha. } \\
\text { b. Keberhasilan } \\
\text { menambahkan nilai } \\
\text { tambah pada barang } \\
\text { baru atau barang } \\
\text { bekas sehingga } \\
\text { memiliki nilai jual } \\
\text { tinggi dan } \\
\text { menambah volume } \\
\text { penjualan. }\end{array}$ \\
\hline
\end{tabular}

\section{HASIL DAN PEMBAHASAN}

Hasil pelatihan yang bertujuan menumbuhkan minat kewirausahaan dalam meningkatkan pendapatan dan juga menyelesaikan masalah limbah anorganik yang menumpuk di rumah adalah dengan menggunakan cara penambahan nilai dengan memilih 
metode decoupage dimana metode ini diyakini sebagai strategi yang tepat diberikan kepada mitra di Gambirsari RW 03, Kelurahan Kadipiro, Kecamatan Banjarsari, Surakarta.

Penambahan nilai tambah terhadap produk barang baru dan bekas ini menjadikan kekuatan memotivasi dalam meningkatkan kretifitas para ibu rumah tangga dalam menyelesaikan limbah anorganik rumah tangga dan menjual produk tersebut untuk meningkatkan pendapatan keluarga. Sampah rumah tangga seperti kaleng bekas dan nampan bekas dapat bernilai jual tinggi setelah dipoles dengan metode decoupage. Produk baru yang semula masih minim penggunaan dan pemanfaatannya berubah menjadi bernilai harga kompetitif dengan menggunakan sentuhan metode decoupage. 
Berikut ini adalah produk-produk dari limbah rumah tangga dan juga produk baru yang sudah mendapatkan nilai tambah :

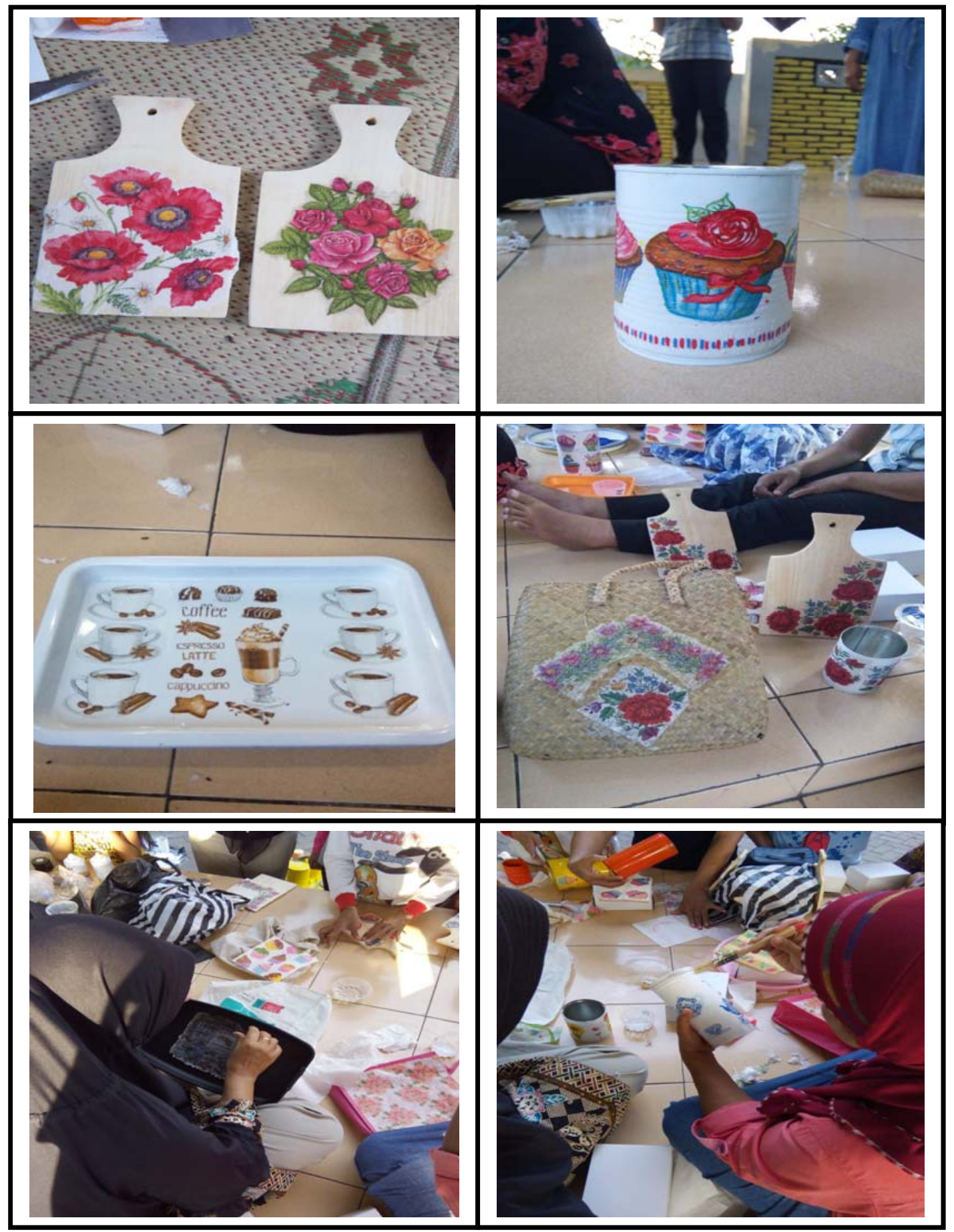

Gambar 1 : Hasil produk dari limbah rumah tangga yang diberikan nilai tambah sehingga dapat dipasarkan dengan harga yang tinggi. 


\section{KESIMPULAN DAN SARAN}

Kegiatan pengabdian pada masyarakat berupa pelatihan penambahan nilai barang baru dan barang bekas tersebut memberi dampak positif terhadap motivasi berwirausaha dalam mewujudkan kesejahteraan masyarakat khususnya pada masyarakat yang tinggal di Gambirsari RW 03, Kelurahan Kadipiro, Kecamatan Banjarsari, Kota Suarakarta. Berdasarkan hasil kegiatan pelatihan penambahan nilai barang baru dan barang bekas, dapat dikemukakan beberapa kesimpulan yaitu:

a. Limbah anorganik merupakan sampah yang dapat diolah dan diberikan nilai tambah.

b. Dengan menggunakan berbagai macam metode salah satunya dengan menggunakan metode decoupage, sampah anorganik yang sering menjadi masalah dalam rumah tangga dapat terselesaikan.

c. Bagi mitra yang berwirausaha barang yang dapat ditambahkan nilai tambah agar nilai jual lebih tinggi pelatihan pelatihan penambahan nilai barang baru dan barang bekas sangat bermanfaat bagi mereka.

d. Pelatihan penambahan nilai barang baru dan barang bekas menambah wawasan bagi mitra untuk dapat berkreasi tentang pemanfaatan limbah rumah tangga dan penambahan nilai tambah barang.

Berdasarkan evaluasi atas kegiatan pengabdian masyarakat yang telah dilakukan menggunakan dua tahapan evaluasi yaitu penilaian hasil produk dan keberlanjutan produktifitas dari mitra :

a) Produk kerajinan decoupage yang menggunakan bahan dasar barang bekas dan barang baru memiliki indikator : (1) kerapian, (2) presisi bentuk napkin atau semacamnya ke dalam media yang telah disediakan atau ditetapkan dan media pilihan mitra, (3) perpaduan warna napkin dan cat atau pilox, (4) modifikasi atau kreatifitas. Berdasarkan kriteria tersebut didapatkan hasil evaluasi penilaian yang menunjukkan sebagai berikut : (1) ada $30 \%$ hasil karya kerajinan decoupage yang dibuat oleh peserta menunjukkan hasil yang 
baik yaitu hasil produk halus seolah penambahan nilai yang diberikan seperti sebuah lukisan kanvas, (2) ada 40\% hasil karya kerajinan decoupage yang dibuat oleh peserta menunjukkan hasil yang cukup baik yaitu hasil produk halus akan tetapi masih ada sisisisi penambahan nilai yang diberikan tidak dapat menghasilkan hasil yang maksimal sesuai harapan, dan (3) ada 20\% hasil karya kerajinan decoupage yang dibuat peserta menunjukkan hasil yang kurang baik yaitu hasil produk kurang halus dan penambahan nilai yang diberikan masih jauh dari pelatihan yang diharapkan. Hal ini dapat dijelaskan karena sebagaian dari $20 \%$ mitra harus terdorong untuk malkukan rutinitas dalam mengembangkan daya cipta dan kreasinya.

b) Evaluasi mengenai keberlanjutan produktivitas dari para peserta pelatihan adalah Lebih dari $50 \%$ peserta pelatihan ingin mengembangkan sebagai home industri yang dapat membantu menjaga kebersihan lingkungan dan dapat menambah pendapatan keluarga. Beberapa diantaranya menginginkan cara yang tepat untuk dapat mempromosikan atau menjual produk kerajinan decoupage yang telah dibuatnya kepada orang lain. Setengah dari peserta pelatihan masih ragu akan kemampuannya untuk mengembangkan usaha ini karena berbagai alas an salah satunya sibuk mengurus rumah tangga. Keberlanjutan dari produk decoupage ini dapat dikembangkan dengan berbagai seni penambahan nilai sehingga membuat produk decoupage ini dapat dijual dengan harga yang tinggi. 


\section{DAFTAR PUSTAKA}

2007. Pengembangan Ekonomi Kreatif Indonesia, Departemen Perdagangan Republik Indonesia. Lihat Jerusalem Florencia.

Aisyah Nurul Fitriana, Irwan Noor, Ainul Hayat, 2014, Pengembangan Industri Kreatif Di Kota Batu (Studi tentang Industri Kreatif Sektor Kerajinan di Kota Batu) Jurnal Administrasi Publik (JAP), Vol. 2 No. 2, Hal. 281-286.

Basu Swastha dan Ibnu Sukotjo, 2009, Strategi Bisnis Modern, Penerbit Liberty, Yogyakarta

Bebassari, Sri, 2008, Integrated Municipal Solid Waste Management toward ZERO WASTE Approach, Center for Assessment and Application of Environmental Technology, Jakarta, diakses melalui http://www.pudsea.ugm.ac.id/ document/ bebassari.pdf, pada hari kamis, 27 Agustus 2015.

Bertens, K., 2010, Pengantar Etika Bisnis, Penerbit Kanisius, Yogyakarta

Buchari Alma, 2014, Kewirausahaan, Penerbit Alfabeta, Bandung

Cipta Soekanto, S, 2002, Sosiologi Suatu Pengantar. Jakarta : PT. Raja Grafindo Persada.

Hendro, 2014, Dasar-dasar Kewirausahaan, Penerbit Erlangga, Jakarta

James Stoner, Freeman E., dan Gilbert J.R., 2014, Manajemen Bisnis. Edisi Indonesia Gramedia, Jakarta.

Kementerian Pariwisata dan Ekonomi Kreatif RI, 2014, Ekonomi Kreatif : Kekuatan Baru Indonesia Menuju 2025, Jakarta.

Marliani, Novi, 2014, Pemanfaatan Limbah Rumah Tangga (Sampah Anorganik) Sebagai Bentuk Implementasi Dari Pendidikan Lingkungan Hidup, Jurnal Formatif 4(2): 124132.

Murniati, D.E, 2009, Peran Perguruan Tinggi Dalam Triple Helix Sebagai Upaya Pengembangan Industri Kreati, Seminar Nasional Peran Pendidikan Kejuruan Dalam Pengembangan Industri Kreatif, Jurusan PTBB FT UNY.

Nitisusatro, M., 2012, Perilaku Konsumen dalam Perspektif Kewirausahaan, Alfabeta, Bandung 
Nitisusastro, M., 2015, Kewirausahaan dan Manajemen Usaha Kecil, Penerbit Erlangga, Jakarta.

Puspa Rini \& Siti Czafrani, 2010, Pengembangan Ekonomi Kreatif Berbasis Kearifan Lokal Oleh Pemuda Dalam Rangka Menjawab Tantangan Ekonomi Global, Jurnal UI Untuk Bangsa Seri Sosial dan Humaniora Volume 1.

Rhenald Kasali, 2010, Wirausaha Mandiri, PT. Gramedia Pustaka Utama, Jakarta

Simatupang, T.M. 2008. Industri Kreatif Indonesia. Bandung: Sekolah Bisnis dan Manajemen, Institut Teknologi Bandung.

Soekartawi, 2012, Faktor-faktor Produksi, Penerbit Salemba Empat, Jakarta

UNDP/UNCTAD, 2008, Creative Economy, Report 2008, Geneva-New York: UNDP, UNCTAD. 